\title{
Preferensi Masyarakat Terhadap Sistem Prabayar dan Pascabayar untuk Jaringan Gas Rumah Tangga di Wilayah Cikarang
}

\author{
Faisal Samsuri ${ }^{1}$, Joni Welman Simatupang ${ }^{2 *}$, Rafael Ryan Putra ${ }^{3}$, Abdul Wahid ${ }^{4}$ \\ ${ }^{1,2,3,4}$ Program Studi Teknik Elektro, Fakultas Teknik, President University, Cikarang - 17550, Indonesia \\ *Koresponden email: joniwsmtp@ president.ac.id
}

Diterima: 8 April 2021

Disetujui: 27 April 2021

\begin{abstract}
Government, through the Head of the Communication Bureau, Public Information Services and Cooperation, Ministry of Energy and Mineral Resources, conveyed a plan to build household gas networks in more than 50 districts and cities that aim to balance the mix of fossil energy use in society. The prepaid system is a payment system that allows users to enjoy services after making a payment. It aims to limit the service as needed, while the postpaid system allows its users to use the service indefinitely during the time span given by the service provider. Currently, the household gas network is equipped with postpaid meters, but it does not rule out the possibility of a prepaid system being applied if it is able to provide better convenience and comfort. Based on the research we conducted to determine public response of Cikarang society against the payment system, as much as $55 \%$ of the total sample studied preferred to use the postpaid system rather than the prepaid system on the household gas network. However, it is possible to use prepaid payment system for household gas networks (respondent's result is 35\%) if the supporting facilities are continuously improved and developed for better service in the future.
\end{abstract}

Keywords: Cikarang, household gas network, energy mixture, payment system, prepaid, postpaid

\begin{abstract}
Abstrak
Pemerintah melalui Kepala Biro Komunikasi, Layanan Informasi Publik dan Kerjasama, Kementerian ESDM, menyampaikan rencana pembangunan jaringan gas rumah tangga di lebih dari 50 kabupaten dan kota yang bertujuan untuk menyeimbangkan bauran penggunaan energi fosil di masyarakat. Sistem prabayar merupakan suatu sistem pembayaran yang memungkinkan penggunanya untuk menikmati layanan setelah melakukan pembayaran. Hal ini bertujuan untuk membatasi layanan sesuai kebutuhan, sedangkan sistem pascabayar memungkinkan penggunanya untuk menggunakan layanan tanpa batas selama rentang waktu yang diberikan oleh penyedia layanan. Saat ini, jaringan gas rumah tangga telah dilengkapi dengan meter pascabayar, namun tidak menutup kemungkinan sistem prabayar diaplikasikan apabila mampu memberikan kemudahan dan kenyamanan yang lebih baik. Berdasarkan penelitian untuk mengetahui respon masyarakat Cikarang terhadap sistem pembayaran tersebut, sebanyak 55\% dari total sampel yang diteliti lebih memilih untuk menggunakan sistem pascabayar daripada sistem prabayar pada jaringan gas rumah tangga. Namun, tidak menutup kemungkinan untuk menggunakan sistem pembayaran prabayar pada jaringan gas rumah tangga (hasil responden sebesar 35\%) apabila fasilitas pendukungnya terus diperbaiki dan dikembangkan untuk pelayanan yang lebih baik di masa yang akan datang.

Kata Kunci: bauran energi, Cikarang, sistem pembayaran, prabayar, pascabayar, jaringan gas rumah tangga
\end{abstract}

\section{Pendahuluan}

Dewasa ini, pemerintah tengah berupaya keras untuk sosialisasi mengenai penggunaan gas alam, baik untuk kebutuhan industri maupun kebutuhan rumah tangga. Hal ini dikarenakan bauran energi yang digunakan oleh masyarakat Indonesia sangat mencerminkan ketergantungan terhadap minyak bumi dan batu bara. Berdasarkan jurnal yang dipublikasi oleh Kementerian ESDM, pada tahun 2019, sekitar 49,7\% sumber energi yang digunakan oleh masyarakat adalah berasal dari minyak bumi, 24,5\% berasal dari batu bara, $20,1 \%$ berasal dari gas alam dan sisanya berasal dari energi terbarukan seperti yang diterangkan oleh Gambar 1. 
Sementara itu, ketersediaan bahan bakar minyak bumi semakin menipis sehingga memicu terjadinya kelangkaan di tengah kebutuhan masyarakat yang begitu tinggi dan juga sifatnya yang tidak terbarukan [1]. Oleh karena itu, penggunaan sumber energi alternatif, khususnya gas alam, diharapkan mampu menjadi solusi bagi kebutuhan masyarakat akan energi serta membantu mengamankan cadangan sumber energi, yang apabila tidak ditanggulangi dengan tepat, akan menimbulkan krisis energi yang memiliki dampak krusial pada sektor-sektor lainnya.

\section{Bauran penggunaan energi tahun 2019 di Indonesia}

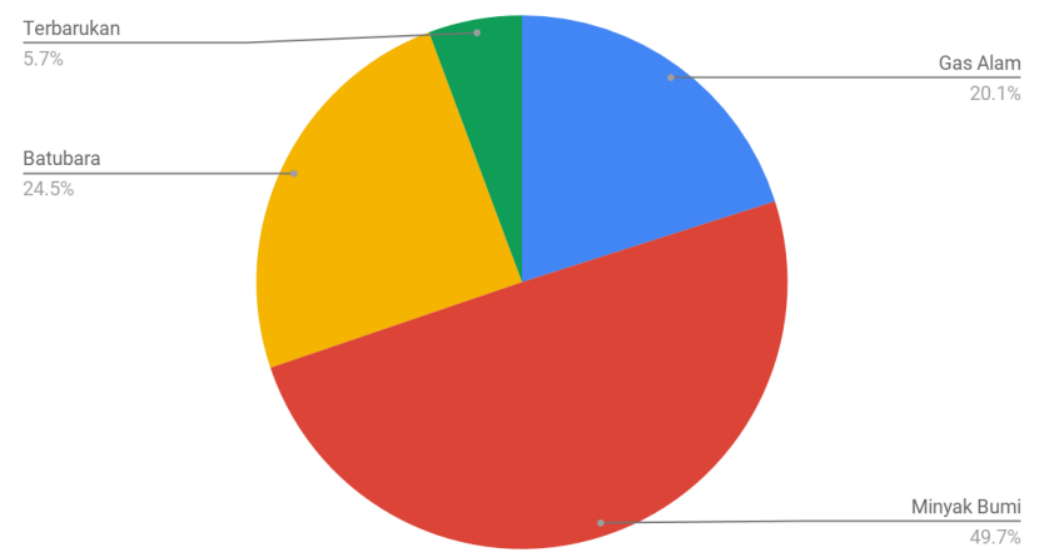

Gambar 1. Bauran penggunaan energi pada tahun 2019 [2].

Salah satu solusi yang ditawarkan pemerintah adalah dengan menyalurkan gas secara langsung ke perumahan penduduk dan juga industri. Khusus pada sektor rumah tangga, pemerintah membangun sistem jaringan gas untuk rumah tangga melalui pipa-pipa gas yang terhubung ke rumah-rumah.

Berdasarkan pernyataan yang diuraikan oleh Kementerian ESDM melalui Kepala Biro Komunikasi, Layanan Informasi Publik dan Kerjasama, melalui redaksi salah satu kanal berita pada tanggal 24 Juni 2019, menjelaskan bahwa pemerintah akan membangun jaringan gas sebanyak lebih dari 290,000 sambungan di 53 kabupaten dan kota. Penggunaan jaringan gas, menurut narasumber, mampu memberikan kemudahan bagi konsumen untuk mendapatkan pasokan gas rumah tangga secara lebih mudah, murah dan aman dibandingkan dengan penggunaan tabung LPG [3]. Pendistribusian LPG melalui jaringan gas ke rumah-rumah tangga secara langsung akan membutuhkan infrastruktur yang mampu menjamin keamanan, kemudahan dan kenyamanan konsumen. Diantara fasilitas pendukung infrastruktur tersebut adalah alat ukur dan sistem pembayaran.

Sistem pembayaran dan alat ukur tidak jarang menjadi pertimbangan masyarakat dalam memilih layanan. Sebagai contohnya adalah meteran KWH yang digunakan untuk jaringan listrik. Beragam opini muncul dari perbedaan sistem pembayaran untuk jaringan listrik. Ada masyarakat yang merasa terbantu dengan sistem prabayar yang baru-baru ini diperkenalkan oleh PLN, ada juga masyarakat yang tidak mau beralih dari sistem pembayaran pascabayar dikarenakan fasilitas-fasilitas pascabayar yang tidak tersedia di sistem prabayar.

Menurut sebuah penelitian yang bertujuan untuk mengetahui kepuasan konsumen berdasarkan sistem pembayaran [4], terdapat perbedaan signifikan antara kepuasan pelanggan listrik prabayar dan pascabayar. Penelitian tersebut menggunakan metode Importance Performance Analysis, yang mana merupakan suatu metode yang digunakan untuk mengetahui kepuasan pelanggan dengan cara mengukur tingkat kepentingan dan pelaksanaannya [5].

Kesimpulan dari penelitian tersebut adalah kepuasan pelanggan listrik prabayar yang lebih tinggi dibandingkan dengan pelanggan listrik pascabayar ditinjau dari berbagai aspek yang dihimpun dalam Importance Performance Matrix, dan juga ditunjukkan oleh nilai hasil T-test yang lebih tinggi pada pelanggan listrik prabayar dibandingkan dengan listrik pascabayar. Sehingga, berdasarkan hasil penelitian tersebut, sistem pembayaran patut juga diperhatikan oleh penyedia layanan, dalam hal ini penyuplai gas yang 
akan didistribusikan ke rumah tangga, sehingga masyarakat dan penyedia layanan bersama-sama memperoleh keuntungan dari pelayanan yang tersedia.

Oleh sebab itu, tujuan penelitian ini adalah untuk mengetahui preferensi masyarakat, khususnya di wilayah Cikarang, terhadap sistem pembayaran yang akan diterapkan pada jaringan gas rumah tangga, yang nantinya dapat dijadikan referensi oleh peneliti lain atau industri terkait untuk mempertimbangkan penyediaan sistem pembayaran, khususnya prabayar, pada jaringan gas rumah tangga.

\section{Kajian Pustaka}

\section{Jaringan Gas Rumah Tangga}

Jaringan gas adalah jaringan pipa distribusi yang dibangun dan dioperasikan untuk penyediaan dan pendistribusian gas bumi untuk rumah tangga dan pelanggan kecil [6]. Ini merupakan suatu program yang digagas oleh pemerintah dalam rangka menyeimbangkan bauran penggunaan energi di masyarakat dengan mengalirkan gas melalui sambungan pipa dari penyuplai gas ke rumah-rumah. Pemanfaatan gas alam sendiri telah diprakarsai oleh PT. Pertamina pada tahun 2007 dengan tujuan agar ketergantungan masyarakat terhadap bahan bakar minyak dapat dikurangi dan terwujudnya fuel security of supply, yaitu mengamankan ketersediaan cadangan bahan bakar yang apabila tidak ditanggulangi dengan baik, dapat mengakibatkan kelangkaan. Pemerintah sendiri menargetkan sebesar $30 \%$ penggunaan gas alam bersama dengan sumber energi lain di masyarakat pada tahun 2025 seperti ditunjukkan oleh Gambar 2.

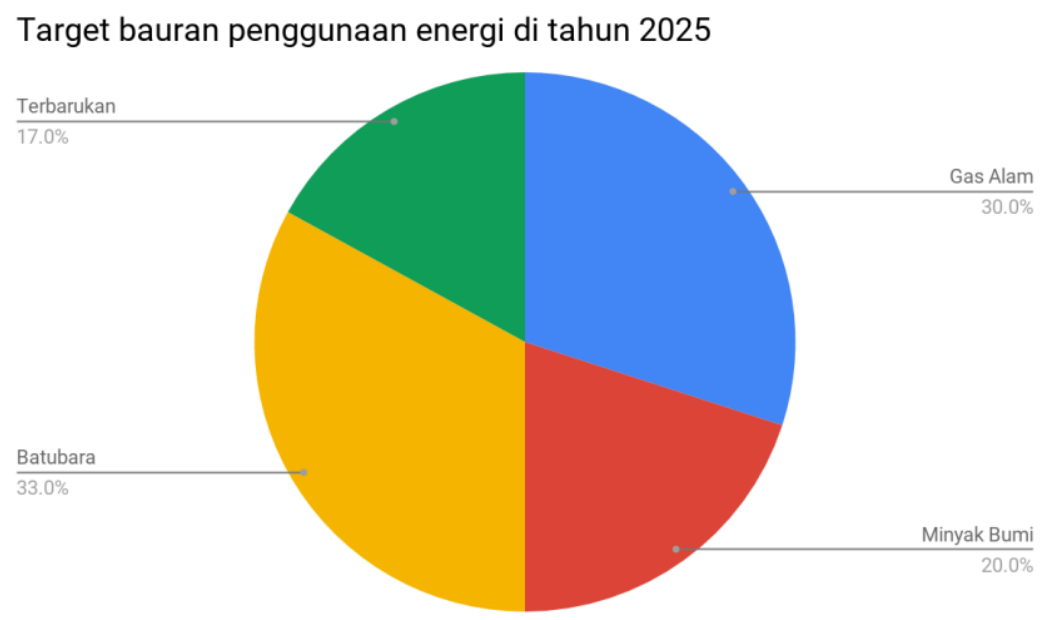

Gambar 2. Target bauran penggunaan energi di tahun 2025 [2].

Saat ini, sebagian besar masyarakat telah diperkenalkan pada pemanfaatan gas alam melalui tabung LPG. Tabung LPG memiliki variasi ukuran $3 \mathrm{~kg}$ dan $12 \mathrm{~kg}$ untuk penggunaan sehari-hari. Permintaan gas LPG selalu meningkat dari waktu ke waktu seiring dengan perkembangan kegiatan perekonomian dan industri. Hal ini dikarenakan penggunaan LPG dinilai memiliki beberapa keunggulan dibandingkan dengan penggunaan BBM, seperti lebih hemat dan bersih sehingga lebih ramah lingkungan dan efisien dari segi biaya.

Namun pemanfaatan gas LPG melalui tabung ini sendiri bukan tanpa masalah. Di antara masalahmasalah yang sering ditemui pada penggunaan tabung adalah kebocoran gas yang mampu mengakibatkan kebakaran. Hal ini diakibatkan oleh kerusakan segel karet pada tabung, serta regulator dan kompor gas yang tidak memenuhi standar SNI, sehingga tidak dapat menjamin keamanan pada saat digunakan [7].

Selain masalah pada penggunaan, masalah pada pendistribusian juga terjadi pada pemanfaatan gas LPG. Pendistribusian berbasis tabung yang disebar ke masyarakat rentan mengalami kelangkaan, yang sebagian disebabkan oleh penimbunan tabung oleh oknum-oknum distributor [8]. Selain itu, pendistribusian yang tidak merata juga sering kali mengakibatkan kelangkaan di beberapa wilayah [9]. Masalah-masalah tersebut diyakini menghambat tujuan pemerintah untuk meningkatkan penggunaan gas LPG di masyarakat, sehingga dibutuhkan suatu solusi yang lebih efektif untuk membantu pendistribusian secara efisien. Salah satu terobosan pemerintah untuk menangani permasalahan tersebut adalah melalui jaringan gas rumah tangga. 


\section{Sistem Pembayaran Prabayar dan Pascabayar}

Sistem pembayaran prabayar (pre-paid) adalah sistem pembayaran yang memungkinkan pengguna untuk membayar terlebih dahulu suatu layanan atau produk sebelum digunakan [10]. Sistem prabayar banyak dijumpai digunakan pada berbagai macam layanan atau produk, seperti jaringan telepon seluler, listrik PLN, dan sebagainya. Sebagai contohnya adalah jaringan listrik PLN dengan KWH meter prabayar. KWH meter prabayar dilengkapi dengan chip dan memori yang sudah ditandai dengan nomor seri, atau nomor meter. Nomor seri atau nomor meter ini bersifat unik satu sama lain, yang mana berfungsi sebagai alamat dari suatu KWH meter, salah satu fungsi lainnya adalah untuk pengisian token.

Token adalah jumlah debit dalam kurs tertentu yang dikonversi dalam besaran KWH, atau lebih dikenal dengan istilah pulsa. Pengguna membayarkan sejumlah uang terlebih dahulu kepada penjual, kemudian penjual akan mengidentifikasi nomor meter tersebut dan memberikan voucher berisi pulsa dengan nomor unik untuk diinput pada KWH meter.

Terdapat beberapa keunggulan dalam penggunaan sistem prabayar seperti berikut [11]:

1. Pengendalian penggunaan listrik dapat lebih baik, karena pembayaran yang dilakukan di awal dapat digunakan untuk membatasi konsumsi.

2. Perbaikan sistem pengukuran karena perangkat elektronik yang digunakan adalah elektronis dengan ketelitian dan keamanan yang lebih tinggi (tergantung pada instrumen yang digunakan oleh penyedia).

3. Mengurangi kesalahan penagihan yang disebabkan human error.

Namun, sistem prabayar juga memiliki beberapa kekurangan sebagai berikut:

1. Harus mengisi ulang setiap kali token habis.

2. Token habis pada waktu yang tidak dapat diprediksi, sehingga layanan dihentikan sampai token diisi kembali.

3. Ketika koneksi internet bermasalah, maka pengisian token harus ditunda sampai koneksi internet kembali normal.

Sistem pembayaran pascabayar (post-paid) merupakan kebalikan dari sistem pembayaran prabayar, yaitu pengguna dapat menikmati layanan terlebih dahulu sebelum membayar. Sistem pascabayar juga dapat dijumpai di berbagai layanan atau produk, seperti jaringan komunikasi seluler maupun telepon rumah, air PDAM, listrik PLN, jaringan gas rumah tangga, dan sebagainya.

Sistem pascabayar memungkinkan pengguna untuk menggunakan layanan terlebih dahulu setelah terdaftar di penyedia untuk waktu tertentu. Setelah tengat waktu yang ditentukan, tagihan akan diberikan untuk kemudian dibayarkan oleh pengguna. Tagihan bisa berupa invoice melalui e-mail, SMS, atau petugas yang mendatangi alamat pengguna layanan.

Keunggulan-keunggulan yang terdapat pada sistem pascabayar adalah sebagai berikut:

1. Layanan tersedia setiap saat tanpa perlu khawatir kehabisan token.

2. Tidak perlu repot mengisi ulang token.

Sistem pascabayar juga memiliki beberapa kekurangan, diantaranya adalah sebagai berikut:

1. Tagihan membengkak dikarenakan penggunaan tidak terkendali.

2. Terdapat denda dan bahkan pemutusan layanan apabila terlambat membayar.

3. Kesalahan pencatatan oleh petugas, sehingga harus membayar lebih besar dari layanan yang diperoleh.

\section{Alat Ukur Untuk Jaringan Gas Rumah Tangga}

Jaringan gas rumah tangga saat ini menggunakan meter gas pascabayar seperti tertera pada Gambar 3. Prinsip kerja dari meter gas tersebut adalah dengan memanfaatkan prinsip operasi rotary-type positive displacement, prinsip ini memungkinkan pengukuran volumetrik dengan perpindahan gas dalam jumlah tertentu. Prinsip operasi ini terjadi dalam rongga yang dibentuk antara ruang internal pada meter dan juga bagian berputar dari mekanisme tersebut, dalam hal ini gerigi yang berputar karena dorongan fluida. 


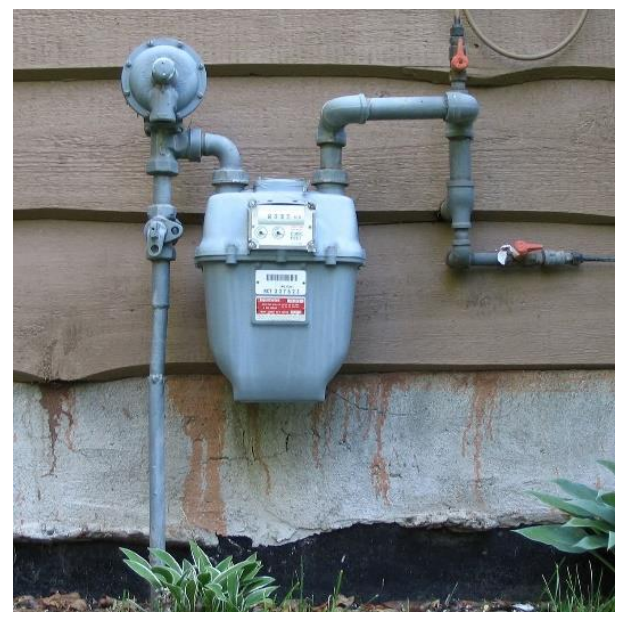

Gambar 3. Meter gas pascabayar [12].

Pada Gambar 4, diilustrasikan pendorong berbentuk angka 8 bergerak seiring dengan tekanan pada inlet dan outlet selama gas pada keluaran digunakan. Pendorong berputar tersebut memisah gas menjadi kecil, terukur pada ruang dan dihitung dengan menggunakan indeks mekanik.
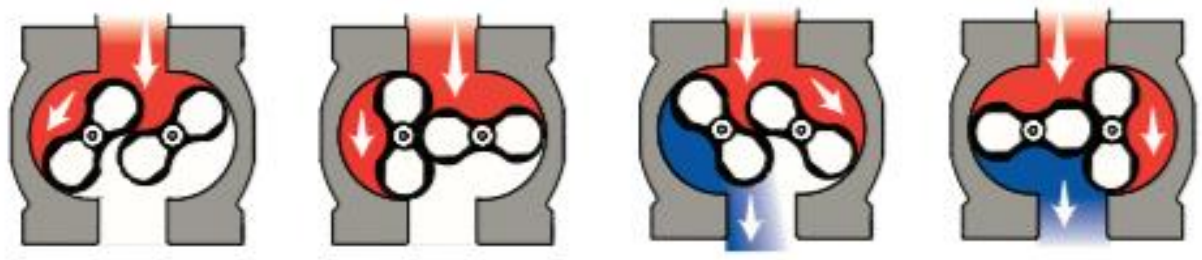

Gambar 4. Prinsip kerja rotary-type positive displacement [13].

Saat pendorong kiri berputar menuju posisi vertikal, gas memasuki rongga sebelah kiri yang dibentuk antara pendorong dan ruang. Ketika pendorong kiri mencapai posisi vertikal, volume gas terukur terperangkap di rongga sebelah kiri. Seiring dengan pendorong yang terus berputar, volume gas di rongga kiri dilepaskan. Secara simultan, gas memasuki rongga kanan yang dibentuk antara pendorong kanan dan ruang. Karena perputaran berlanjut, pendorong kanan mencapai posisi vertikal dan volume gas terukur terperangkap di rongga sebelah kanan dan kemudian dilepaskan seiring perputaran pendorong. Proses terus terjadi secara berulang selama gas pada downstream digunakan oleh beban.

Perputaran pendorong terhubung dengan mekanisme gerigi/gear-box yang selanjutnya terhubung kepada indeks mekanik. Indeks mekanik ini terhubung pada putaran angka-angka yang ditunjukkan pada penunjuk angka yang disesuaikan dengan volume gas pada downstream. Nilai terukur kemudian dicatat oleh penyedia layanan setiap bulannya dan disesuaikan dengan biaya penggunaan berdasar satuan volume gas yang digunakan untuk kemudian dibayar oleh pengguna di akhir waktu yang ditentukan.

\section{Metode Penelitian}

\section{Studi Literatur}

Studi literatur adalah penelitian yang dilakukan berdasarkan karya tertulis, termasuk hasil penelitian baik yang telah maupun yang belum dipublikasikan [14]. Studi literatur pada penelitian ini digunakan untuk menyusun kajian pustaka yang digunakan untuk menyusun opini melalui pendahuluan, rumusan masalah dan tujuan penelitian, juga untuk menopang hasil penelitian melalui studi kasus.

Pada penelitian kali ini, dilakukan penelusuran melalui Google Cendikia (suatu fasilitas dari Google yang menghimpun berbagai hasil penelitian dari berbagai universitas, lembaga riset seperti LIPI, maupun institusi pemerintah seperti kementerian yang mengadakan penelitian untuk topik tertentu) dengan dua kata kunci pertama dan kedua berturut-turut yaitu "sistem prabayar dan pascabayar" dan juga "jaringan gas rumah tangga". 
Berdasarkan kata kunci pertama, diperoleh sebanyak 752 hasil. Sementara berdasarkan kata kunci kedua, diperoleh sebanyak 21.200 hasil. Kemudian kedua kata kunci dikombinasikan menjadi "jaringan gas rumah tangga prabayar" dan "jaringan gas rumah tangga pascabayar", keduanya menunjukkan hasil 1.400 dan 1.340 artikel berturut-turut, namun untuk hasil paling populer, sistem pembayaran selalu terkait dengan jaringan listrik sampai di halaman ke-4 pencarian, sampai di halaman ke-5 pencarian, tidak ditemukan artikel terkait sistem pembayaran dengan jaringan gas rumah tangga secara khusus.

Hal ini menunjukkan bahwa penelitian mengenai preferensi masyarakat terhadap sistem pembayaran untuk jaringan gas rumah tangga masih sangat jarang dilakukan dibandingkan dengan sistem pembayaran untuk jaringan listrik yang cukup mudah ditemui.

\section{Studi Kasus}

Dalam penelitian ini, digunakan metode studi kasus sebagai metode utama yang termasuk dalam penelitian kualitatif-deskriptif: analisis data penelitian terfokus pada kasus tertentu [15]. Kasus yang dimaksud adalah sistem pembayaran yang sudah pernah diterapkan pada jaringan listrik dikarenakan sudah banyak digunakan sehingga informasi mengenai kualitas layanan akan mudah didapat, untuk kemudian dijadikan acuan terhadap penerapannya pada sistem jaringan gas rumah tangga. Metode studi kasus dimaksudkan untuk memperkuat reliabilitas hasil tinjauan literatur secara sistematis serta membantu menarik kesimpulan dari penelitian berdasarkan data yang diperoleh secara empiris.

Studi kasus dilakukan di suatu wilayah perumahan di daerah Cikarang dengan populasi sebanyak 100 kepala keluarga, kemudian diambil sampel secara acak 20 responden sebagai perwakilan $20 \%$ dari populasi. Pengambilan data dilakukan dengan cara penyebaran angket yang berisi 12 pertanyaan mengenai penggunaan sistem prabayar dan pascabayar pada jaringan listrik, pengetahuan mengenai program pemerintah yang bernama jaringan gas rumah tangga, dan preferensi responden terhadap sistem pembayaran yang lebih baik untuk diterapkan apabila responden mendapatkan layanan jaringan gas rumah tangga [16].

\section{Hasil Penelitian Dan Diskusi}

Berdasarkan hasil penelitian yang diperoleh melalui studi kasus, diperoleh hasil sebagai berikut.

\section{Apakah responden membayar sendiri tagihan listriknya?}

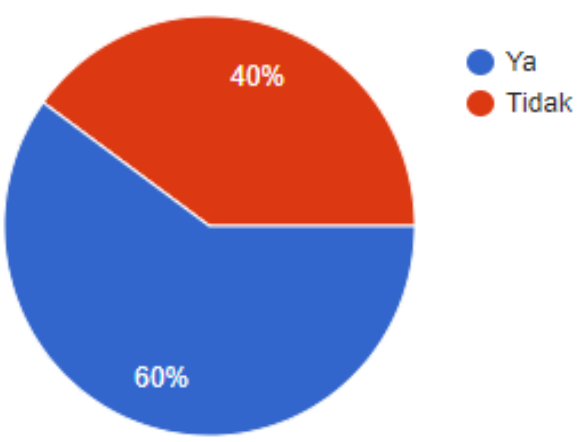

Gambar 5. Apakah responden membayar sendiri tagihan listriknya?

Berdasarkan data angket di atas, $60 \%$ menjawab ya, $40 \%$ menjawab tidak, yang berarti $60 \%$ responden merasakan perbedaan pembayaran melalui pascabayar dan prabayar sehingga bisa memberikan pendapat secara langsung untuk pertanyaan berikutnya. Sedangkan $40 \%$ responden menjawab pertanyaan berikutnya berdasarkan pengamatan atau tidak bisa memberikan pendapatnya secara langsung. 


\section{Berapa biaya penggunaan listrik responden dalam sebulan?}

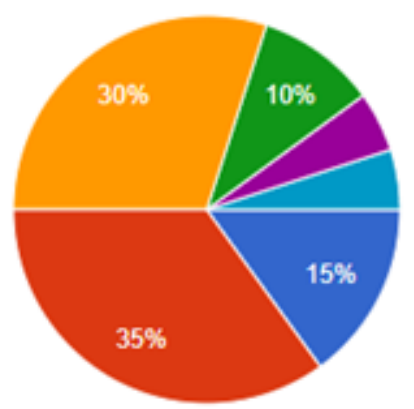

$R p 20.000$,- s/d Rp100.000,-

$R p 100.000,-s / d \operatorname{Rp} 300.000$,-

$R p 300.000$,- s/d Rp500.000,-

$R p 500.000,-s / d$ Rp1.000.000,

Rp100.000,-

300.000

Gambar 6. Berapa biaya penggunaan listrik responden dalam sebulan?

Berdasarkan data pada angket, 35\% biaya penggunaan listrik di angka Rp.100,000.00 Rp.300,000.00 yang kemungkinan besar responden memiliki kapasitas daya listrik sebesar 900W. Sedangkan $30 \%$ biaya penggunaan listrik di angka Rp.300,000.00 - Rp.500,000.00 yang kemungkinan besar responden memiliki kapasitas daya listrik sebesar 1,300W.

\section{Keperluan penggunaan listrik responden}

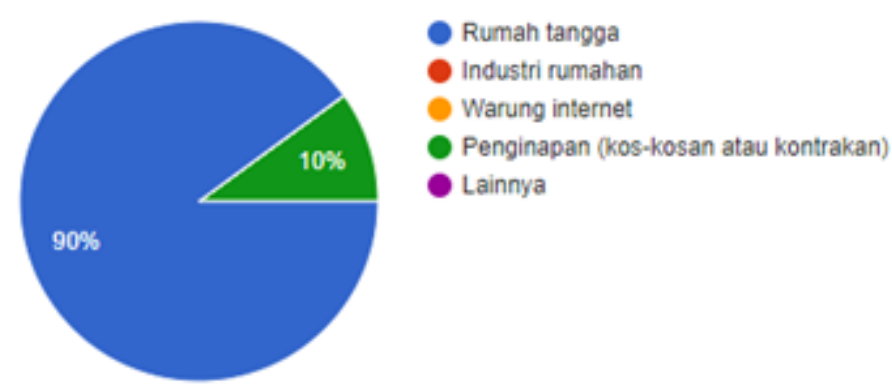

Gambar 7. Keperluan penggunaan listrik responden

Dari data angket didapat 90\% responden menggunakan listrik untuk keperluan rumah tangga. 10\% responden menggunakan listrik untuk bisnis kos-kosan. Ini berarti bila responden sudah mendapat sistem jaringan gas ke setiap rumah, maka penggunaannya tidak akan banyak.

\section{Sistem pembayaran yang digunakan responden}

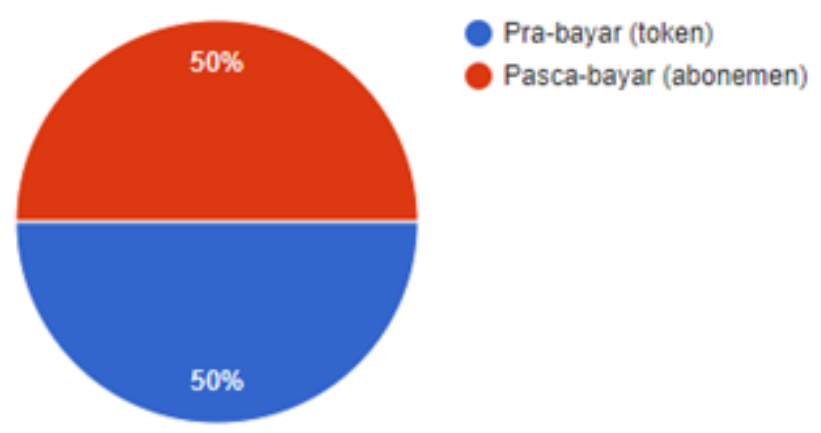

Gambar 8. Sistem pembayaran yang digunakan responden 
Dari data angket yang sudah diperoleh, 50\% responden menggunakan sistem prabayar dan 50\% responden menggunakan sistem pascabayar pada jaringan listrik. Hal ini menunjukkan 20 orang responden dapat memberikan jawaban yang seimbang mengenai sistem pembayaran pascabayar dan prabayar yang sudah diterapkan pada jaringan listrik.

\section{Mengapa beralih dari pascabayar ke prabayar?}

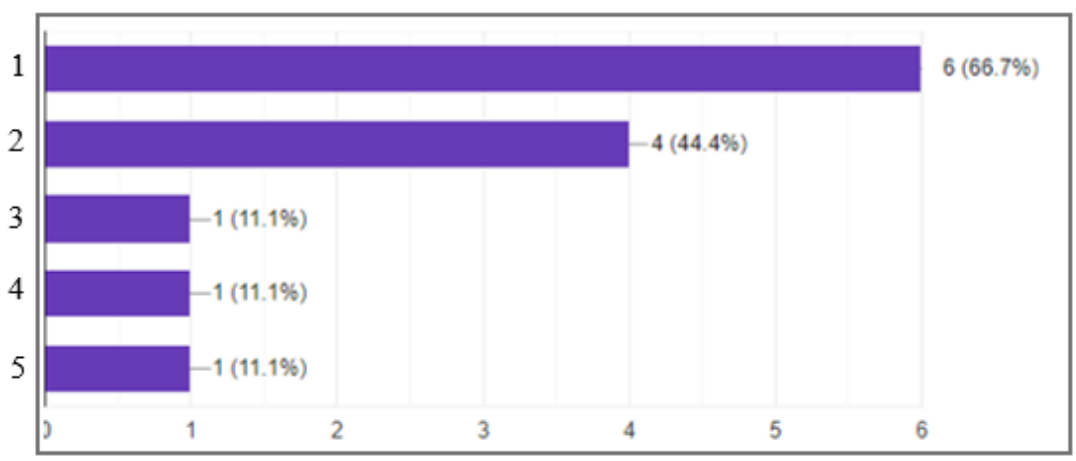

Gambar 9. Mengapa beralih dari pascabayar ke prabayar?

Keterangan:

1. Kemudahan transaksi

2. Pengeluaran lebih terkontrol

3. Transparansi penggunaan (menghindari kesalahan pencatatan biaya oleh penagih)

4. Tidak ada denda keterlambatan

5. Banyak memberikan fasilitas cashback

Berdasarkan data berikut, sistem prabayar memiliki kemudahan transaksi dan pengeluaran lebih terkontrol seiring dengan penggunaannya. Sistem prabayar pun diuntungkan dengan adanya fasilitas cashback dari metode pembayaran yang ada di masyarakat.

\section{Mengapa tidak beralih dari pascabayar ke prabayar?}

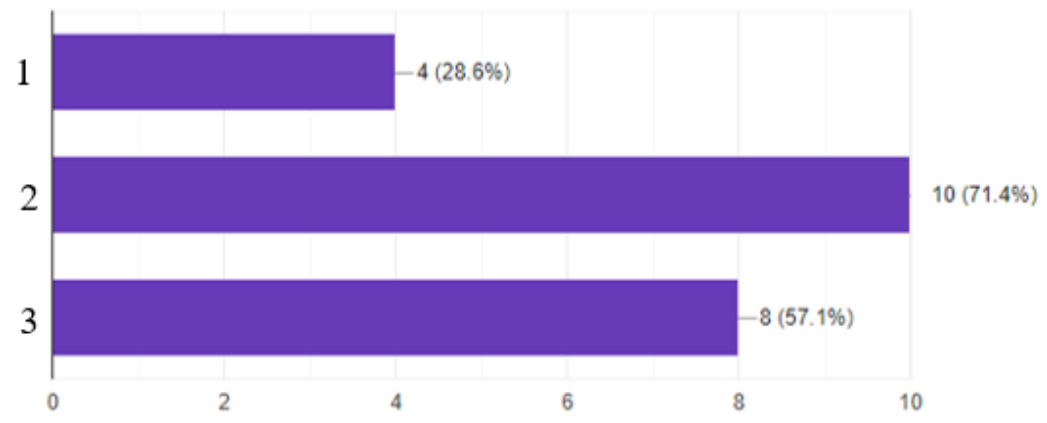

Gambar 10. Mengapa tidak beralih dari pascabayar ke prabayar?

Keterangan:

1. Tidak membutuhkan voucher

2. Tidak ada limitasi penggunaan

3. Pembayaran berkala (terjadwal)

Bila dilihat dari jumlah respon pertanyaan "Mengapa beralih dari pascabayar ke prabayar?", responden lebih banyak menanggapi pertanyaan "Mengapa tidak beralih dari pascabayar ke prabayar?" yang berarti responden lebih antusias dengan sistem pascabayar. Ditandai dengan pernyataan nomor 2 (tidak ada limitasi penggunaan), ini berarti responden lebih senang bila penggunaan listrik tidak terbatas sampai jatuh tempo pembayaran (terjadwal). 


\section{Layanan yang diharapkan tersedia pada sistem prabayar}

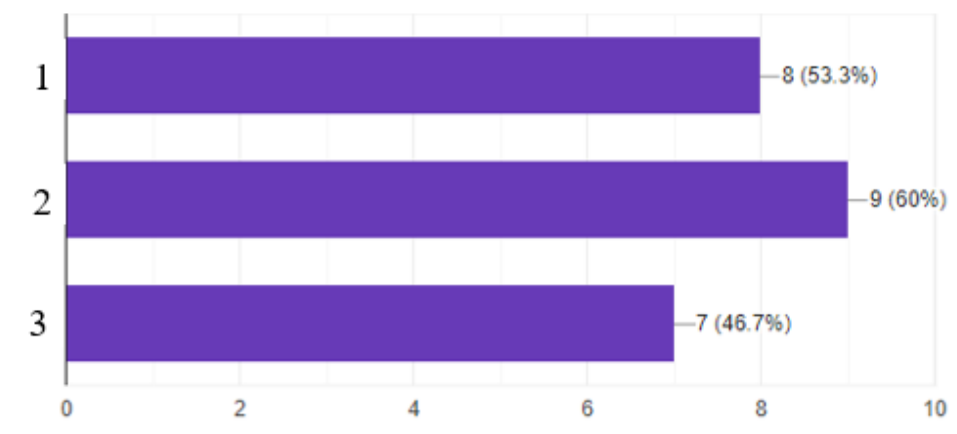

Gambar 11. Layanan yang diharapkan tersedia pada sistem prabayar

\section{Keterangan:}

1. Pemberitahuan langsung ke handphone pengguna mengenai prediksi habisnya token

2. Pengisian token dapat dilakukan melalui handphone pengguna

3. Menggunakan sistem NFC dalam pengisian

Melihat respon pertanyaan nomor "Mengapa beralih dari pascabayar ke prabayar?" dan "Mengapa tidak beralih dari pascabayar ke prabayar?", ada kemungkinan alasan mengapa responden tidak beralih karena masih ada yang harus dikembangkan pada sistem prabayar dan yang mendominasi adalah pengisian token melalui handphone pengguna tanpa harus input manual.

\section{Layanan yang diharapkan tersedia pada sistem pascabayar}

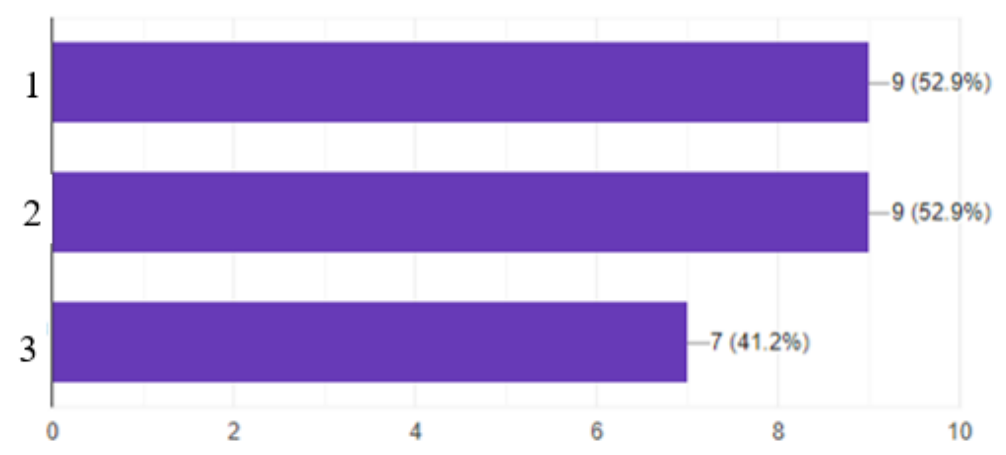

Gambar 12. Layanan yang diharapkan tersedia pada sistem pascabayar

Keterangan :

1. Jumlah penggunaan terkoneksi server agar dapat dilihat langsung

2. Punya sistem pembatas penggunaan listrik bulanan sesuai keinginan pengguna

3. Mengirimkan peringatan kepada pengguna jika penggunaan bulanan mendekati batas yang ditetapkan

Berdasarkan data di atas, responden antusias dalam mengamati penggunaan listrik mereka masingmasing, terlihat pada pernyataan "Jumlah penggunaan terkoneksi server agar dapat dilihat langsung". Responden pun memiliki antusias dalam menghemat penggunaan listrik mereka walaupun dalam penggunaannya tidak dibatasi. 


\section{Apakah responden mengetahui program jaringan gas rumah tangga?}

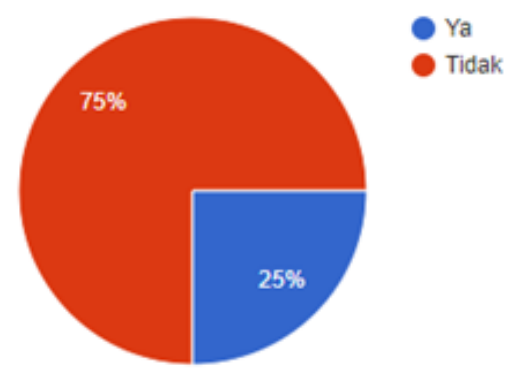

Gambar 13. Apakah responden mengetahui program jaringan gas rumah tangga?

Sebanyak $25 \%$ responden mengetahui program pemerintah berupa jaringan gas rumah tangga, dan sebanyak $75 \%$ responden tidak mengetahui program tersebut. Hal ini tentu saja dikarenakan pengambilan sampel penelitian di daerah yang belum tersedia layanan jaringan gas rumah tangga dan masih menggunakan tabung LPG.

\section{Pendapat responden mengenai program jaringan gas rumah tangga}

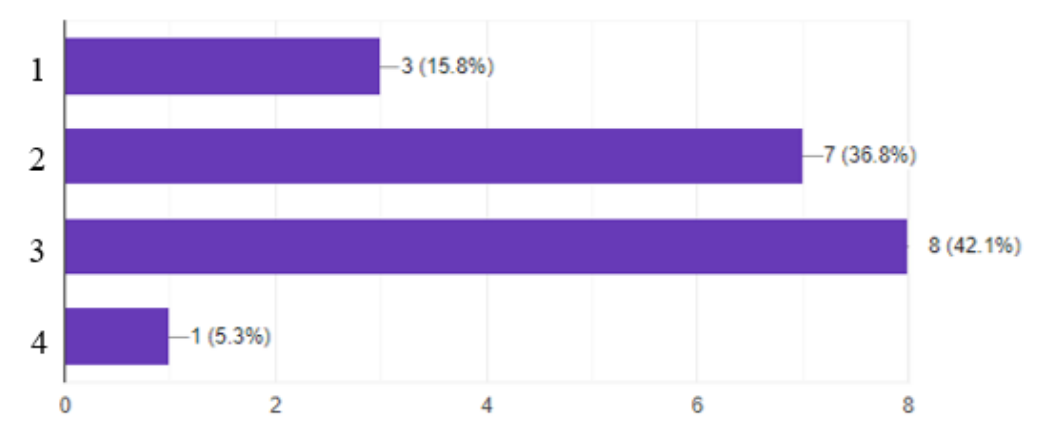

Gambar 14. Pendapat responden mengenai program jaringan gas rumah tangga

Keterangan:

1. Biasa saja

2. Bisa lebih murah (tidak ada biaya transportasi pada saat distribusi)

3. Berbahaya (kebocoran gas di jalan-jalan)

4. Tidak tahu

Dari jawaban yang diberikan responden di atas, walaupun masih banyak yang belum mengetahui tentang rencana jaringan gas rumah tangga, 36,8\% merespon positif terhadap program ini. Namun $42 \%$ diantaranya memikirkan bahaya yang kemungkinan terjadi pada sistem ini.

\section{Kemungkinan yang terjadi pada meteran gas}

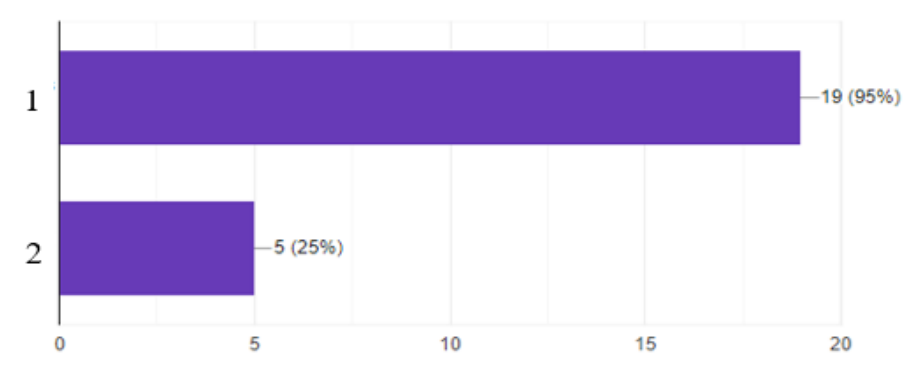

Gambar 15. Kemungkinan yang terjadi pada meteran gas. 
Keterangan:

1. Valve atau katup penutup aliran gas bocor halus, sehingga meteran gas tetap berjalan apabila ada kebocoran setelah meteran gas

2. Meteran gas menghitung lebih cepat atau lebih lambat akibat enduransi alat ukur yang menurun seiring waktu sehingga menyebabkan kesalahan pencatatan

Berdasarkan data di atas, responden juga mengkhawatirkan terjadinya kebocoran yang menyebabkan kesalahan pencatatan. Fenomena ini, menurut responden, sangat umum ditemui pada meter air yang mengalami kebocoran pada saluran-salurannya. Sehingga tidak menutup kemungkinan kebocoran serupa terjadi juga pada saluran gas sehingga meter gas terus mencatat pada saat gas tidak digunakan.

\section{Apakah memungkinkan untuk menggunakan sistem prabayar pada jaringan gas rumah tangga?}
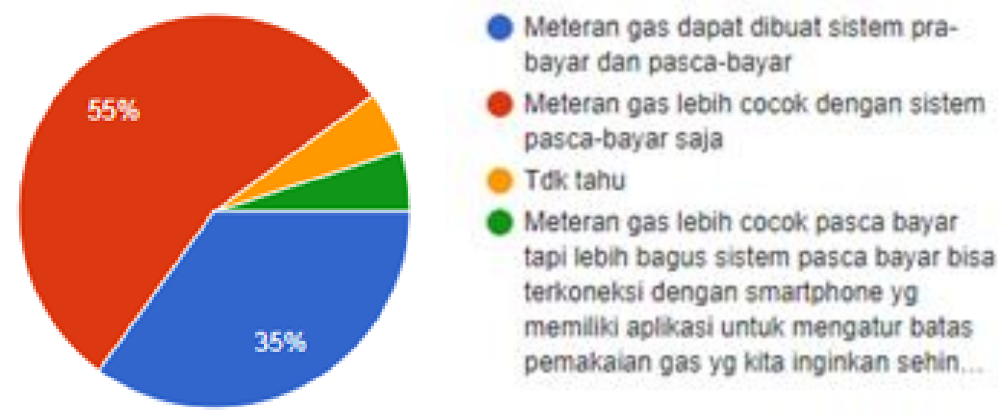

Gambar 16. Apakah memungkinkan untuk menggunakan sistem prabayar pada jaringan gas rumah tangga?

Berdasarkan data di atas, 55\% responden berpikir bahwa meteran gas lebih cocok dengan sistem pascabayar saja. ada pula yang menambahkan sistem pascabayar yang terkoneksi dengan aplikasi untuk mengatur dan menyesuaikan pemakaian dengan kebutuhan sehari-hari, sementara 35\% responden merasa bahwa meteran gas bisa dibuat sistem prabayar dan pascabayar sama seperti jaringan listrik.

\section{Kesimpulan Dan Saran}

Berdasarkan studi kasus, 55\% responden berpendapat bahwa meteran gas lebih cocok hanya menggunakan sistem pascabayar saja. Penyebabnya adalah responden lebih menyukai menggunakan layanan terlebih dahulu sebelum pembayaran daripada membayar terlebih dahulu untuk layanan yang mereka inginkan. Namun demikian, meskipun mayoritas responden lebih memilih sistem pascabayar, sebanyak $35 \%$ juga menyatakan bahwa sistem prabayar memungkinkan untuk digunakan. Ini menunjukkan bahwa tidak menutup kemungkinan sistem prabayar akan diminati oleh responden berdasarkan sampel yang diteliti. Selain itu, sosialisasi mengenai jaringan gas rumah tangga juga dinilai masih kurang masif sehingga sebagian besar responden tidak mengetahui mengenai program jaringan gas rumah tangga. Hal ini tentu saja dapat menghambat tujuan pemerintah untuk menyeimbangkan bauran energi pada dan mengurangi ketergantungan masyarakat terhadap bahan bakar minyak yang begitu tinggi.

Berdasarkan kesimpulan-kesimpulan tersebut, ada beberapa saran yang bisa diberikan sebagai respon dari hasil penelitian ini: memperbaiki sistem pembayaran yang telah tersedia berdasarkan referensi dari responden serta mengetahui efisiensinya secara langsung, melakukan sosialisasi secara lebih intensif kepada masyarakat mengenai penggunaan jaringan gas rumah tangga dalam rangka mensukseskan program pemerintah, dan juga melakukan penelitian lebih lanjut di berbagai tempat untuk mendapatkan hasil yang lebih memadai. Selain itu, apabila memungkinkan, perancangan prototype untuk meter gas prabayar juga akan sangat membantu memberikan gambaran pada masyarakat secara empiris, sehingga dapat dilakukan perbandingan dengan sistem pembayaran yang sudah ada.

\section{Ucapan Terimakasih}

Para penulis berterimakasih kepada para responden yang telah bersedia meluangkan waktu untuk mengisi kuesioner yang kami berikan untuk mendapatkan data sehingga kami bisa melakukan analisa untuk 
mendapatkan kesimpulan penelitian. Juga kepada penulis-penulis atau periset-periset sebelumnya yang telah membuat artikel-artikel yang menjadi sumber referensi untuk membantu menyelesaikan artikel ilmiah ini.

\section{Singkatan}

KWH : Kilo Watt Hour

PLN : Pembangkit Listrik Nasional

PDAM : Perusahaan Daerah Air Minum

LPG : Liquid Petroleum Gas

BBM : Bahan Bakar Minyak

ESDM : Energi dan Sumber Daya Mineral

\section{Referensi}

[1] Novianti, Atiek Rostika dkk. 2016. "Struktur dan Morfologi Elektrolit Apatit Lantanum Silikat Berbahan Dasar Silika Sekam Padi”. Sumedang. Departemen Fisika FMIPA Universitas Padjadjaran

[2] 2018. "Pembangunan Jaringan Gas Bumi Untuk Rumah Tangga". Jakarta. Direktorat Jenderal Minyak dan Gas Bumi, Kementerian ESDM

[3] https://www.liputan6.com/bisnis/read/3996606/bangun-293-ribu-jaringan-gas-rumah-tanggapemerintah-anggarkan-rp-352-t (terakhir diakses pada tanggal 3 Februari 2020)

[4] Ramdlana, Rasyida Leila dan Mukhamad Najib. 2016. "Analisis Perbedaan Kualitas Pelayanan Listrik Pascabayar Dan Listrik Prabayar Terhadap Kepuasan Pelanggan Pada PT PLN (Persero) Area Ciputat". Bogor. Fakultas Ekonomi dan Manajemen Institut Pertanian Bogor

[5] Purnomo, Wirdha. Dyah Riandadari. 2015. "Analisa Kepuasan Pelanggan Terhadap Bengkel Dengan Metode IPA (Importance Performance Analysis) di PT. Arina Parama Jaya Gresik”. Surabaya. Jurusan Teknik Mesin Universitas Negeri Surabaya

[6] Andriawan dkk. 2020. "Pemanfaatan Pengembangan Jaringan Gas Bumi Sebagai Pengganti LPG Rumah Tangga di Kabupaten Bojonegoro - Jawa Timur”. Jakarta. ASIIMETRIK Universitas Pancasila

[7] Lestari, Fatma. Budi Hartono. 2011. "Peningkatan Pengetahuan Dan Keterampilan Masyarakat Tentang Cara Aman Menggunakan Tabung Gas 3 Kg". Jakarta. Fakultas Kesehatan Masyarakat Universitas Indonesia

[8] Effendi, Saladdin Wirawan. 2017. "Analisis Tingkat Harga Yang Dterima Konsumen Gas Lpg 3 Kg Ditinjau Dari Aspek Penawaran (Studi Kasus Kabupaten/Kota XYZ)”. Purwokerto. FEB Universitas Jenderal Soedirman

[9] Utomo, Septana Cahyo. 2019. “Tinjauan Yuridis Distribusi Gas Dari Agen Ke Pangkalan”. Surakarta. Universitas Muhammadiyah Surakarta

[10] 2016. "Kamus Besar Bahasa Indonesia (Edisi Kelima)". Jakarta. Kementerian Pendidikan dan Kebudayaan Republik Indonesia

[11] Bintoro, Andik. 2017. "Analisa Pengaruh Variasi Tegangan Pada KWH Pascabayar Dan Prabayar Terhadap Jumlah Putaran KWH Meter”. D.I. Aceh. Universitas Malikussaleh

[12] https://commons.wikimedia.org/wiki/User:RadRafe commonswiki\#/media/File:Gas_meter.JPG (terakhir diakses pada tanggal 3 Februari 2020)

[13] Elster American Meter Company LLC. 2016. "Elster® Rotary Gas Meter”. Nebraska City, USA. Honeywell International Inc.

[14] Melfianora. 2016. "Penulisan Karya Ilmiah Dengan Studi Literatur". Pekanbaru, Riau. UPT Balai Pelatihan Penyuluh Pertanian

[15] Wahid murni. 2017. "Pemaparan Metode Penelitian Kualitatif". Malang. UIN Maulana Malik Ibrahim

[16] https://docs.google.com/forms/d/1Q2gzddmkFTXPDa3JaWJ7zyaHQniyxjEV2esx2E0wUno/prefill (angket penelitian) 